\title{
IMPLEMENTASI KEBIJAKAN PROGRAM KAWASAN RUMAH PANGAN LESTARI (KRPL) DALAM MENINGKATKAN KESEJAHTERAAN MASYARAKAT
}

\author{
Desy Nafilah Ayuning Tyas \\ Fakultas Ilmu Admiministrasi, Universitas Islam Malang \\ email: desynafilah22@gmail.com
}

\begin{abstract}
ABSTRAK
Menyadari pentingnya diversifikasi pangan, pemerintah telah mengambil berbagai upaya dan kebijakan, salah satu upaya kebijakan tersebut adalah pelaksanaan program Kawasan Rumah Pangan Lestari (KRPL). Tujuan dari penelitian ini adalah: (1) Mengkaji peran aktor dalam melaksanakan pemberdayaan kelompok tani KRPL Kenanga melalui program KRPL, (2) Mengetahui implementasi kebijakan program KRPL, (3) Mengetahui faktor pendukung dan penghambat yang dihadapi dalam melaksanakan pemberdayaan kelompok tani KRPL Kenanga melalui program KRPL di Kelurahan Merjosari. Untuk mencapai tujuan tersebut, peneliti menggunakan jenis penelitian kualitatif dengan pendekatan deskriptif. Lokasi penelitian ini dilaksanakan di Kelurahan Merjosari Kecamatan Lowokwaru Kota Malang. Objek yang diteliti pada penelitian ini adalah Implementasi Kebijakan Program Kawasan Rumah Pangan Lestari (KRPL). Pengumpulan data dilakukan melalui wawancara, observasi dan dokumentasi. Analisis data dilakukan secara deskriptif kualitatif melalui analisis domain, analisis taksonomi, analisis komponensial dan analisis tema budaya. Berdasarkan hasil penelitian menunjukkan bahwa peran Dinas Pertanian dan Ketahanan Pangan Kota Malang adalah sebagai dinamisator, sedangkan peran Kelurahan Merjosari adalah sebagai fasilitator. Untuk peran kelompok tani KRPL Kenanga sendiri adalah memberikan kontribusi terhadap keberlangsungan pangan dan peningkatan keberdayaan kelompok. Implementasi program Kawasan Rumah Pangan Lestari (KRPL) di Kelurahan Merjosari Kecamatan Lowokwaru Kota Malang berjalan efektif, namun pelaksanaan di lapangan masih ditemukan kendala. Bentuk kegiatan implementasi program Kawasan Rumah Pangan Lestari (KRPL) adalah melakukan perencanaan program, pelaksanaan program serta monitoring dan evaluasi. Kawasan Rumah Pangan Lestari (KRPL) adalah memberdayakan rumah tangga dan masyarakat dalam penyediaan sumber pangan dan gizi melalui optimalisasi pemanfaatan pekarangan dan lahan sekitar tempat tinggal. Adapun faktor pendukung yang dihadapi dalam melaksanakan pemberdayaan kelompok tani KRPL Kenanga antara lain partisipasi masyarakat dan kesadaran masyarakat. Adapun faktor yang menjadi penghambat adalah sedikitnya pemahaman anggota kelompok mengenai teknologi produksi atau teknik budidaya tanaman serta jarangnya dilakukan kegiatan pendampingan dan pelatihan kepada anggota KRPL Kenanga.
\end{abstract}

Kata Kunci: implementasi kebijakan, program KRPL, aktor, kendala

\section{PENDAHULUAN}

\section{Latar Belakang}

Dalam era yang semakin berkembang ini, salah satu tuntutan bagi sebuah negara berkembang adalah pembangunan nasional. Pembangunan nasional akan terlaksana dengan baik apabila ada koordinasi dari segenap masyarakatnya. Dalam kerangka otonomi daerah, salah satu komponen yang perlu dikembangkan adalah 
wilayah pedesaan. UU No.6 Tahun 2014 tentang Desa yang merujuk pada Peraturan Pemerintah No.47 Tahun 2015, pelaksanaan Undang-Undang tersebut pada pasal 1 ayat 1 memberikan kesempatan kepada masyarakat desa untuk mengatur dan mengurus rumah tangganya sendiri dengan persyaratan yang diamanatkan serta memperhatikan potensi dan keanekaragaman daerah dalam sistem NKRI.

Kemiskinan di pedesaan merupakan masalah pokok nasional yang penanggulangannya tidak dapat ditunda dan harus menjadi prioritas utama dalam pelaksanaan pembangunan kesejahteraan sosial. Sedangkan Indeks Kedalaman Kemiskinan di Indonesia meningkat menjadi 1,83 pada Maret 2017, dibandingkan dengan di September 2016 sebesar 1,74. Berdasarkan wilayahnya, perdesaan memiliki Indeks Kedalaman Kemiskinan yang lebih tinggi dibandingkan perkotaan per Maret 2017. Di pedesaan sebesar 2,49, di perkotaan 1,24.

Dari data tersebut, disimpulkan per Maret 2017, perdesaan memiliki persoalan kemiskinan lebih besar dibanding perkotaan, karena sebagian besar penduduk pedesaan bermata pencaharian di sektor pertanian, maka dapat dimaknai bahwa tingkat kemiskinan sektor pertanian kondisinya lebih banyak dibanding sektor lainnya.

Permasalahan sebagaimana diatas, diperlukan upaya sungguh-sungguh dalam mengantisipasi kerawanan pangan serta pemenuhan gizi yang ideal. Salah satu upaya yang dapat dilakukan adalah memanfaatkan sumber daya lahan perkarangan disekitar rumah (Ashari et al, 2012). Dengan mengaplikasikan program pemerintahan yaitu Kawasan Rumah Pangan Lestari (KRPL).

Kota Malang merupakan salah satu daerah di Jawa Timur yang melaksanakan program KRPL. Salah satu program KRPL yang berada di Kota Malang adalah KRPL Kenanga yang terletak di Rukun Warga (RW) 11, Villa Bukit Tidar Kelurahan Merjosari Kecamatan Lowokwaru Kota Malang. Program KRPL di lokasi ini sudah dilaksanakan sejak tahun 2015 dibawah bimbingan Dinas Pertanian dan Ketahanan Pangan Kota Malang yang dikelola oleh kelompok ibu-ibu rumah tangga dengan Kelompok Tani Kenanga dan masih berjalan hingga penelitian ini dilakukan. Pemilihan RW 11 Kelurahan Merjosari sebagai tempat pengembangan KRPL adalah berdasarkan rekomendasi pejabat daerah setempat (Lurah). Alasannya menurut Ketua Kelompok KRPL Kenanga di RW tersebut memiliki banyak SDM dan tingkat swadaya tinggi dalam kegiatan apapun.

Meskipun tergolong baru, KRPL Kenanga sudah mendapatkan penghargaan. Hasil yang diperoleh dari penyusunan dan pengembangan program penghijauan pada tahun 2014 telah memberikan kontribusi sebagai Juara Terbaik Kota Sehat. Namun Kelurahan Merjosari masih memiliki hambatan, mengingat lahan garapan KRPL ini adalah masyarakat perkotaan, dimana sebagian masyarakatnya bukan petani sehingga tidak menutup kemungkinan terjadi beberapa hambatan dalam pelaksanaan pengembangannya, seperti sedikitnya pemahaman anggota kelompok mengenai teknologi produksi atau teknik budidaya tanaman dan jarangnya dilakukan kegiatan pendampingan dan pelatihan kepada anggota.

Jadi permasalahan yang muncul pada program ini yaitu kurangnya keterampilan masyarakat dalam menjalankan program KRPL, oleh sebab itu untuk mengatasi kendala program dan supaya tetap berkelanjutan diperlukan kader lingkungan yaitu masyarakat sebagai promotor dan penerus program. Upaya yang efektif untuk menyadarkan manusia tentang pentingnya pelestarian lingkungan hidup adalah melalui jalur masyarakat, dalam hal ini adalah kader lingkungan dengan cara membentuk budaya masyarakat yang berwawasan lingkungan hidup. 
Mengacu pada hal diatas, dapat diketahui bahwa masyarakat di Kelurahan Merjosari yang tergabung dalam Kelompok Tani KRPL Kenanga dalam menerapkan program KRPL masih berjalan kurang maksimal dalam memenuhi tujuan awalnya. Hal ini menjadi kendala terwujudnya Model Kawasan Rumah Pangan Lestari yang benarbenar bisa dijadikan patokan Desa/Kelurahan lainnya, agar program ini tidak hanya diimplementasikan di satu Desa/Kelurahan saja. Diharapkan juga melalui program KRPL, kelompok tani KRPL Kenanga ini dapat lebih berdaya dalam segi hasil panen maupun finansial serta kesejahteraan hidupnya meningkat.

\section{Rumusan Masalah}

Berdasarkan uraian pada latar belakang yang telah dikemukakan di atas, maka rumusan masalah dalam penelitian ini adalah (1) Bagaimanakah peran aktor dalam melaksanakan pemberdayaan kelompok tani KRPL Kenanga melalui program KRPL di Kelurahan Merjosari Kecamatan Lowokwaru Kota Malang? (2) Bagaimanakah implementasi kebijakan program KRPL di Kelurahan Merjosari Kecamatan Lowokwaru Kota Malang? (3) Apa sajakah faktor pendukung dan penghambat yang dihadapi dalam melaksanakan pemberdayaan kelompok tani KRPL Kenanga melalui program KRPL di Kelurahan Merjosari Kecamatan Lowokwaru Kota Malang?

\section{Tujuan Penelitian}

Berdasarkan rumusan masalah diatas, maka tujuan dari penelitian ini adalah untuk: (1) Mengkaji peran aktor dalam melaksanakan pemberdayaan kelompok tani KRPL Kenanga melalui program KRPL, (2) Mengetahui implementasi kebijakan program KRPL, (3) Mengetahui faktor pendukung dan penghambat yang dihadapi dalam melaksanakan pemberdayaan kelompok tani KRPL Kenanga melalui program KRPL di Kelurahan Merjosari.

\section{Manfaat Penelitian}

\section{a. Secara Teoritis}

$>$ Bagi Jurusan Ilmu Administrasi Publik

Sebagai bahan masukan pengembangan ilmu pengetahuan di bidang Administrasi Publik pada umumnya dan masalah implementasi kebijakan program dalam pendekatan pemberdayaan pada khususnya.

$>$ Bagi Mahasiswa

Sebagai pengetahuan dalam meningkatkan khasana keilmuan bidang disiplin ilmu pemerintahan dan bahan untuk penelitian selanjutnya yang berhubungan implementasi kebijakan program KRPL dalam meningkatkan kesejahteraan masyarakat.

$>$ Bagi Penulis

Sebagai sarana peningkatan kemampuan ilmiah penulis, melalui teori-teori yang didapat dalam aspek pemerintahan, menambah pengetahuan penulis untuk dapat memahami lebih jauh bagaimana membantu dan memberdayakan masyarakat dengan memberikan kesempatan penulis untuk menerapkan teori, konsep-konsep yang berkaitan dengan implementasi kebijakan.

\section{b. Secara Praktis}

$>$ Bagi Pemerintah

Sebagai gambaran atau masukan dalam penyelenggaraan dan implementasi serta mengevaluasi setiap kebijakan program yang berhubungan dengan 
pemberdayaan pelaksana program, khususnya di Kelurahan Merjosari Kecamatan Lowokwaru

$>$ Bagi Masyarakat Kelurahan Merjosari dan Kota Malang

Menambah wawasan bagi masyarakat sejauh mana program berjalan dan dijadikan motivasi/penggerak bagi masyarakat untuk meningkatkan partisipasi dan kepedulian masyarakat dalam mendukung program pembangunan desa melalui pemberdayaan.

\section{METODE PENELITIAN}

\section{Jenis dan Pendekatan Penelitian}

Jenis penelitian yang di gunakan dalam penelitian ini adalah jenis penelitian kualitatif dengan pendekatan deskriptif. Penelitian ini bertujuan untuk menemukan, memahami, menjelaskan, dan memperoleh gambaran fenomena-fenomena yang dikaji. Melalui penelitian kualitatif, peneliti dapat mengetahui tanggapan dan persepsi dari berbagai kalangan, seperti kelompok sasaran dalam program KRPL, yakni kelompok tani KRPL Kenanga Kelurahan Merjosari, para pelaku pelaksana program (penyuluh pendamping) dan pemegang kebijakan (Dinas Pertanian dan Ketahanan Pangan Kota Malang).

Melalui penelitian kualitatif, data yang dikumpulkan bukan berupa angka-angka, melainkan data tersebut berasal dari wawancara mendalam, catatan lapangan, dokumen pribadi, catatan memo, dan dokumen resmi lainnya.

\section{Fokus Penelitian}

Menurut Moleong (2000), bahwa "fokus penelitian sangat penting peranannya dalam penelitian, yaitu dapat dijadikan sebagai sarana untuk memandu dan mengarahkan penelitian. Dengan arahan fokus penelitian, peneliti dapat mengetahui secara persis data mana yang perlu dikumpulkan". Dalam penelitian ini yang menjadi fokus penelitian adalah:

a. Peran aktor dalam melaksanakan pemberdayaan kelompok tani KRPL Kenanga melalui kebijakan program KRPL di Kelurahan Merjosari dengan sub fokus:

$>$ Peran Dinas Pertanian dan Ketahanan Pangan dalam melaksanakan pemberdayaan kelompok tani KRPL Kenanga.

$>$ Peran Pemerintah Kelurahan dalam melaksanakan pemberdayaan kelompok tani KRPL Kenanga.

$>$ Peran kelompk tani KRPL Kenanga dalam melaksanakan kebijakan program KRPL.

b. Implementasi kebijakan program KRPL pada kelompok tani KRPL Kenanga di Kelurahan Merjosari dengan sub fokus:

$>$ Proses implementasi kebijakan program KRPL pada kelompok tani KRPL Kenanga di Kelurahan Merjosari.

$>$ Model implementasi best practice kebijakan program KRPL pada kelompok tani KRPL Kenanga di Kelurahan Merjosari.

c. Faktor pendukung dan penghambat yang dihadapi dalam melaksanakan pemberdayaan kelompok tani KRPL Kenanga melalui kebijakan program KRPL di Kelurahan Merjosari dengan sub fokus:

$>$ Faktor pendukung yang dihadapi dalam melaksanakan pemberdayaan kelompok tani KRPL Kenanga.

$>$ Faktor penghambat yang dihadapi dalam melaksanakan pemberdayaan kelompok tani KRPL Kenanga. 


\section{Situs dan Latar Penelitian}

Latar penelitian yang dimaksud disini adalah tempat dimana sebenarnya peneliti menangkap fenomena dari obyek yang diteliti untuk memperoleh data atau informasi yang diperlukan. Latar penelitian ini dilaksanakan di Kelurahan Merjosari Kecamatan Lowokwaru Kota Malang. Sedangkan situs penelitian ini di kelompok tani KRPL Kenanga Kelurahan Merjosari Kecamatan Lowokwaru Kota Malang.

\section{Jenis Data dan Sumber Data}

\section{a. Jenis Data}

Menurut Lofland seperti yang dikutip oleh Moleong (2002, hal 112) sumber data dalam penelitian kualitatif adalah kata-kata dan tindakan, selebihnya adalah datadata tambahan seperti dokumen dan lain-lain. Berdasarkan sumber datanya, dapat digolongkan 2 jenis data:

$>$ Data Primer

Data primer adalah hasil wawancara dengan responden berupa kata-kata, tindakan, keterangan serta informasi yang dikumpulkan, mengamati dan mencatat kejadian yang terjadi dilapangan.

$>$ Data sekunder

Data sekunder adalah dokumen-dokumen seperti studi pustaka yang digunakan untuk memperoleh data dan informasi yang berhubungan menunjang dengan permasalahan penelitian. Data dan informasi diperoleh melalui studi daftar pustaka melalui buku, lapangan penelitian, karya ilmiah, dokumen-dokumen, table, gambar, arsip pihak terkait, catatan-catatan, artikel dan lain-lain.

\section{b. Sumber Data}

Sumber data adalah orang atau subyek yang dapat memberikan informasi yang dibutuhkan pada penelitian. Adapun yang menjadi sumber data primer dalam penelitian ini adalah:

> Aparat pemegang kebijakan program KRPL, yang merupakan program dari Kementrian Pertanian dan berada dalam kelompok program pemberdayaan. Dalam hal ini data primer diperoleh dari aparat pemegang kebijakan program KRPL yang bersangkutan atau daerah setempat yaitu Dinas Pertanian dan Ketahanan Pangan Kota Malang. Data atau dokumen yang diteliti merupakan dokumen yang berhubungan dengan implementasi kebijakan program KRPL yang berjalan di Kelurahan Merjosari, apakah sudah berjalan efektif dan berdampak terhadap kesejahteraan masyarakat.

$>$ Ketua dan Anggota Kelompok tani KRPL Kenanga Kelurahan Merjosari sebagai pelaksana kebijakan program KRPL, dalam hal ini data yang diperlukan berkaitan dengan bagaimana proses implementasi program KRPL yang selama ini sudah berjalan.

$>$ Kelompok masyarakat yang peduli program KRPL di Kelurahan Merjosari Kecamatan Lowokwaru, dalam hal ini dapat mencakup para pelaku pelaksana program (penyuluh pendamping lapangan). Sedangkan data yang diperlukan adalah sejauhmana masyarakat merasakan dampak dari implementasi kebijakan program KRPL

Sedangkan yang menjadi sumber data sekunder dalam penelitian ini adalah:

> Kelurahan Merjosari Kecamatan Lowokwaru Kota Malang, dalam hal ini data yang diperlukan adalah data yang berhubungan dengan sejauhmana proses implementasi kebijakan program yang telah dilaksanakan 
$>$ Dinas Pertanian dan Ketahanan Pangan Kota Malang. Dalam hal ini data yang diperlukan adalah bagaimana implementasi kebijakan program KRPL yang telah diatur dalam Peraturan Menteri Pertanian No.15 tentang Peningkatan Diversifikasi dan Ketahanan Pangan dan sejauh mana hal ini dapat meningkatkan kesejahteraan masyarakat.

\section{Teknik Pengambilan Sampling}

Dalam penelitian kualitatif tidak menggunakan istilah populasi, tetapi oleh Spradley dinamakan "sosial situation" atau situasi sosial yang terdiri atas tiga elemen yaitu: tempat (place), pelaku (actors), dan aktivitas (activity) yang berinteraksi secara sinergis.

Sampel dalam penelitian ini menggunakan teknik purposive sampling dengan tujuan kriteria sampel yang diperoleh benar-benar sesuai dengan penelitian yang akan dilakukan yaitu hanya menggali informasi dari key informan. Purposive sampling adalah teknik pengambilan sampel sumber data dengan pertimbangan tertentu.

Lincoln dan Guba (1985:40) mengemukakan bahwa "penentuan sampel dalam penelitian kualitatif (naturalistik) sangat berbeda dengan penentuan sampel dalam penelitian konvensional (kuantitatif). Penentuan sampel dalam penelitian kualitatif tidak didasarkan perhitungan statistik. Sampel yang dipilih berfungsi untuk mendapatkan informasi yang maksimum, bukan untuk digeneralisasikan".

Jadi, penentuan sampel dalam penelitian kualitatif dilakukan saat peneliti mulai memasuki lapangan dan selama penelitian berlangsung (emergent sampling design). Seperti telah dikutip diatas, dalam purposive sampling, besar sampel ditentukan oleh pertimbangan informasi.

\section{Teknik Pengumpulan Data}

Teknik pengumpulan data yang digunakan dalam penelitian ini adalah sebagai berikut:

a. Observasi

Observasi adalah kegiatan pengamatan terhadap suatu objek dengan menggunakan seluruh alat indera manusia. Observasi ini digunakan untuk penelitian yang telah direncanakan secara sistematik tentang bagaimana implementasi kebijakan program KRPL yang berlangsung di Kelurahan Merjosari. Metode observasi digunakan untuk mengumpulkan data dari keadaan yang ingin diamati, yaitu proses pelaksanaan Percepatan Diversifikasi Konsumsi Pangan melalui Konsep KRPL. Observasi dilakukan secara langsung terhadap subjek penelitian di lokasi penelitian. Pengumpulan data dilakukan dengan mengamati dan mencapai gejala-gejala yang tampak, serta pola perilaku subjek penelitian.

b. Wawancara

Wawancara adalah sebuah dialog yang dilakukan oleh pewawancara untuk memperoleh informasi dari terwawancara. Sumber data yang diwawancarai pada penelitian ini adalah aparat pelaksana kebijakan program KRPL, dalam hal ini adalah Dinas Pertanian dan Ketahanan Pangan Kota Malang, serta PPL pendamping kelompok tani KRPL Kenanga. Selain itu, wawancara juga dilakukan dengan sumber lain yang diyakini mampu memberikan jawaban yang mendukung penelitian, seperti anggota KRPL Kenanga. Proses wawancara dilakukan dengan teknik wawancara yang dipandu menggunakan bantuan pedoman wawancara. 


\section{c. Dokumentasi}

Dokumentasi berasal dari kata dokumen, yang artinya barang-barang tertulis. Didalam melaksanakan metode dokumentasi, peneliti menyelidiki benda-benda tertulis seperti buku-buku literatur, majalah, dokumen, peraturan-peraturan, notulen rapat, catatan harian, dan sebagainya yang berhubungan implementasi kebijakan program KRPL.

Dalam metode dokumentasi ini, peneliti mengumpulkan data-data yang dimiliki lembaga, dan peneliti memformulasikan serta menyusunnya dalam bentuk laporan yang sesuai kebutuhan yang diperlukan. Metode ini membantu penulis mengumpulkan informasi tentang berbagai bentuk aktifitas, khususnya aktifitas tentang Implementasi Kebijakan program KRPL dalam meningkatkan kesejahteraan masyarakat dengan studi pada pemberdayaan kelompok tani KRPL Kenanga di Kelurahan Merjosari.

\section{Keabsahan Data}

Trianggulasi adalah cara yang paling umum digunakan dalam penjaminan validitas data dalam penelitian kualitatif. Trianggulasi merupakan teknik pemeriksaan keabsahan data dengan memanfaatkan sesuatu yang lain diluar data itu untuk keperluan pengecekan data atau sebagai pembanding terhadap data tersebut. Keabsahan data dalam penelitian ini menggunakan trianggulasi, Sugiyono (2006:273274), menjelaskan ada tiga macam trianggulasi. Ketiga trianggulasi tersebut yaitu triangulasi sumber, pengumpulan data, dan waktu.

Penjelasan dari ketiga triangulasi tersebut yaitu : 1) Trianggulasi sumber adalah trianggulasi untuk menguji kredibilitas data dengan cara mengecek data yang diperoleh melalui beberapa sumber. 2) Trianggulasi teknik adalah alat untuk menguji kredibilitas data dengan mengecek data yang sama namun dengan alat berbeda. 3) Trianggulasi waktu adalah triangulasi yang sering mempengaruhi data. Data dikumpulkan dengan teknik wawancara dipagi, siang, maupun malam hari memberikan data valid sehingga lebih kredibel.

\section{Analisis Data}

Analisis data adalah kegiatan mengelola data yang diperoleh dari pustaka dan lapangan menjadi seperangkat hasil, baik dalam penemuan baru maupun dalam bentuk kebenaran hipotesa. Metode ini merupakan langkah yang kritis dalam penelitian, hal ini digunakan untuk menjelaskan data yang terkumpul dari hasil penelitian.

Analisis Model Spradley adalah analisis data yang dilakukan pada saat pengumpulan data berlangsung dan setelah selesai pengumpulan data dalam periode tertentu. Teknik analisis data kualitatif pada penelitian ini menggunakan model fenomenologi Spradley, yang secara keseluruhan proses penelitiannya terdiri atas: pengamatan deskriptif, analisis domain, pengamatan terfokus, analisis taksonomi, pengamatan terpilih, analisis komponensial, dan diakhiri dengan analisis tema (Moleong 2010:302). Proses tersebut dapat disederhanakan dalam empat tahap sebagai berikut:

\section{$>$ Analisis Domain}

Analisis domain yaitu peneliti memasuki obyek penelitian berupa situasi sosial yang terdiri atas, place, actor, dan activity, selanjutnya melakukan analisis domain, dan melakukan observasi. Analisis domain pada umumnya dilakukan untuk memperoleh gambaran yang umum dan menyeluruh tentang situasi sosial yang 
diteliti atau objek penelitian. Data yang diperoleh dari observasi, wawancara, dan studi dokumen. Hasilnya berupa gambaran umum tentang objek yang diteliti. Dalam analisis ini informasi yang diperoleh belum mendalam, masih di permukaan, namun sudah menemukan domain-domain atau kategori dari situasi sosial yang diteliti.

$>$ Analisis taksonomi

Analisis taksonomi adalah analisis terhadap keseluruhan data yang terkumpul berdasarkan domain yang ditetapkan. Dengan demikian domain yang telah ditetapkan menjadi cover term oleh peneliti dapat diurai lebih rinci dan mendalam melalui analisis taksonomi ini. Setelah cover term atau domain terpilih maka melalui pencarian data lain dan analisis taksonomi akan ditemukan fokus domain yang dipilih dan lebih mengerucutkan penelitian selanjutnya, dilanjutkan analisis komponensial sebagai tahap akhir sebelum di temukan conclusion atau kesimpulan.

$>$ Analisis Komponensial

Pada analisis komponensial yang dicari untuk diorganisasikan dalam domain bukanlah serupa domain, tetapi justru memiliki perbedaan atas yang kontras. Data yang dicari melalui observasi, wawancara dan dokumentasi yang terseleksi. Dengan teknik pengumpulan data yang bersifat triangulasi tersebut sejumlah data spesifik akan ditemukan. Pada tahap ini, peneliti mencoba mengkontraskan antar unsur dalam ranah yang diperoleh dan dipilah-pilah, selanjutnya dibuat kategorisasi yang relevan.

$>$ Analisis Tema Budaya

Analisis tema budaya (discovering cultural themes), sesungguhnya merupakan upaya mencari "benang merah" yang mengintegrasikan lintas domain yang ada (Sanapiah, 1990). Dengan ditemukan benang merah dari hasil analisis domain, taksonomi dan komponensial tersebut, maka selanjutnya dapat tersusun "konstruksi bangunan" situasi sosial/objek penelitian yang sebelumnya masih belum terfokus, dan setelah dilakukan penelitian, maka menjadi lebih terang atau terfokus, akhirnya kesimpulan dapat dijelaskan secara deskriptif menggunakan predikat. Analisis ini mencoba mengumpulkan sekian banyak tema, fokus budaya, nilai dan simbol-simbol budaya yang ada dalam setiap domain.

Berdasarkan analisis data diatas, maka proses penelitian berangkat dari yang luas kemudian memfokus, dan meluas lagi. Terdapat tahapan analisis data yang dilakukan dalam penelitian kualitatif, yaitu analisis domain, toksomi, komponensial dan analisis tema kultural. Hal ini dapat digambarkan seperti gambar berikut: 


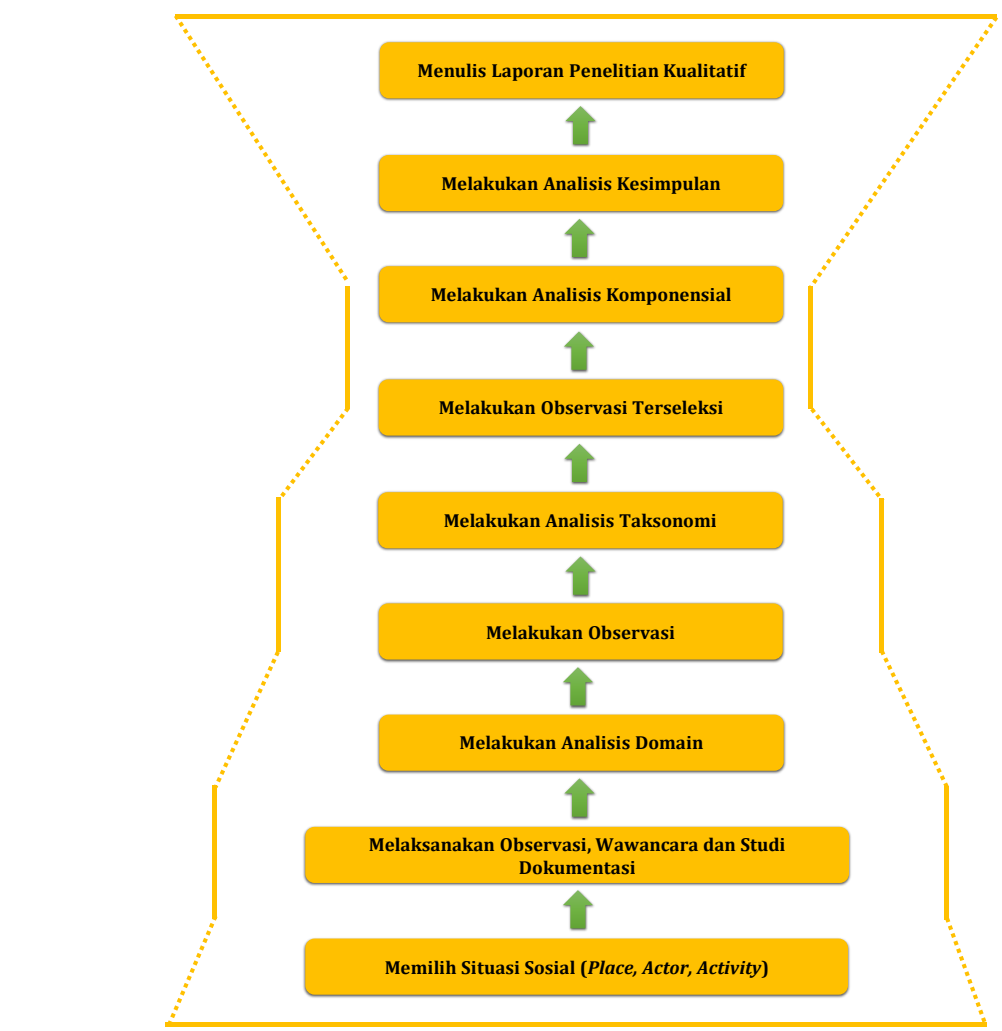

Gambar 1. Tahapan Penelitian Model Spradley Sumber: Metode Penelitian Kuantitatif, Kualitatif dan R\&D (Sugiyono:2016)

\section{HASIL DAN PEMBAHASAN}

1. Peran aktor dalam melaksanakan pemberdayaan kelompok tani KRPL Kenanga melalui kebijakan program KRPL di Kelurahan Merjosari Kecamatan Lowokwaru Kota Malang

\section{a. Peran Dinas Pertanian dan Ketahanan Pangan}

Peran Dinas Pertanian dan Ketahanan Pangan Kota Malang sebagai dinamisator. Jadi sebagai dinamisator, pemerintah berperan melalui pemberian bimbingan dan pengarahan yang intensif dan efektif kepada masyarakat. Selain itu juga berperan sebagai penanggungjawab kegiatan dan lembaga yang membantu menyalurkan penurunan bantuan dana kepada penerima manfaat program yang bersumber dari dana APBN Pusat.

\section{b. Peran Pemerintah Kelurahan Merjosari}

Pemerintah Kelurahan berperan sebagai fasilitator. Sebagai fasilitator, pemerintah kelurahan berusaha menciptakan atau memfasilitasi suasana yang tertib, nyaman dan aman termasuk memfasilitasi tersedianya sarana dan prasarana pembangunan seperti pendampingan. Hal ini dibuktikan dari hasil temuan peneliti bahwa pihak kelurahan ikut mendampingi kegiatan kelompok tani KRPL Kenanga ketika ada beberapa kunjungan dan monitoring. Jadi, peran Pemerintah Kelurahan disini terbatas pada pemberian dukungan dan motivasi, bantuan fasilitas penunjang kegiatan kepada kelompok jika diperlukan dan pemantauan perkembangan kegiatan kelompok. 


\section{c. Peran Kelompok tani KRPL Kenanga}

Peran Kelompok tani KRPL Kenanga telah berperan memberikan kontribusi terhadap keberlangsungan pangan dan peningkatan keberdayaan kelompok. Hal ini dibuktikan dengan banyaknya anggota kelompok yang ikut berperan aktif dan antusias dalam mengikuti program KRPL. Jumlah anggota yang mengikuti program KRPL Kenanga di Kelurahan Merjosari bertambah menjadi 24 orang anggota dari yang awalnya hanya 15 . Dengan adanya partisipasi keikutsertaan kelompok dalam melaksanakan program ini, maka dapat memenuhi ketersediaan pangan dan memberdayakan kelompok, karena tidak harus tergantung dengan pasar. Dengan begitu, maka program ini dapat menyumbang penurunan inflasi yang ada di Kota Malang.

\section{Implementasi kebijakan program KRPL pada kelompok tani KRPL Kenanga di Kelurahan Merjosari Kecamatan Lowokwaru Kota Malang \\ a. Proses implementasi kebijakan program KRPL \\ $>$ Perencanaan}

Perencanaan merupakan tahap awal dari implementasi suatu kebijakan. Berdasarkan hasil temuan peneliti, dapat diketahui bahwa proses implementasi kebijakan program KRPL di Kelurahan Merjosari telah mencapai tujuan yang diharapkan sesuai petunjuk teknis KRPL tahun 2018 yaitu memberdayakan rumah tangga dan masyarakat dalam penyediaan sumber pangan dan gizi melalui optimalisasi pemanfaatan pekarangan dan lahan sekitar tempat tinggal, serta meningkatkan kesadaran, peran dan partisipasi masyarakat dalam mewujudkan pola konsumsi pangan yang beragam, bergizi seimbang dan aman (B2SA).

Perencanaan dilakukan di setiap tingkat implementator yang meliputi Dinas Pertanian dan Ketahanan Pangan Kota Malang, penyuluh lapangan, serta di kelompok penerima manfaat program. Hasil penelitian menujukkan bahwa perencanaan sudah disusun dengan tujuan yang diharapkan dengan diawali tahap penyusunan dokumen perencanaan. Oleh karena itu, dapat dikatakan bahwa tahap perencanaan program KRPL telah dilakukan dengan baik.

Dalam implementasi program KRPL, dapat disimpulkan bahwa perencanaan yang dilaksanakan sudah baik. Hal ini disebabkan perencanaan telah memenuhi dua kriteria jenis rencana, yaitu ada kebijakan dan anggaran. Kebijakan yang menjadi dasar hukum kegiatan KRPL adalah Peraturan Presiden Nomor 22 Tahun 2009 Tentang Kebijakan Percepatan Penganekaragaman Konsumsi Pangan Berbasis Sumber Daya Lokal, yang ditindaklanjuti oleh Peraturan Menteri Pertanian Nomor 43 Tahun 2009 Tentang Gerakan Percepatan Penganekaragaman Konsumsi Pangan Berbasis Sumber Daya Lokal. Program KRPL juga telah memiliki anggaran yang jelas sebagaimana yang dikemukakan oleh informan penelitian.

\section{$>$ Pelaksanaan}

Tahap selanjutnya dalam implementasi kebijakan program KRPL adalah tahap pelaksanaan program. Berdasarkan hasil temuan peneliti, pelaksanaan program KRPL Kenanga dilakukan melalui beberapa langkah, diantaranya mulai dari melaksanakan sosialisasi di tingkat kota dan kelurahan dengan mengundang masyarakat dan tokoh masyarakat untuk memberikan pemahaman tentang tujuan, sasaran dan manfaat program yang akan dilaksanakan. 
Sosialisasi yang dilakukan oleh Koordinator Penyuluh P2KP Dinas Pertanian dan Ketahanan Pangan Kota Malang tersebut dilakukan dengan cara membimbing dan mendampingi pelaksanaan kegiatan KRPL, memberikan pelatihan dan membantu kelompok dalam menyusun Rencana Kerja dan Kebutuhan Anggaran (RKKA) kelompok sesuai dengan kebutuhan belanja kelompok untuk penanaman dan pemeliharaan.

Selanjutnya dilakukan tahapan penumbuhan, tahap pengembangan dan tahap kemandirian sesuai dengan petunjuk teknis Optimalisasi Pemanfaatan Lahan Pekarangan Melalui KRPL. Dalam pelaksanaannya, untuk KRPL Kenanga sudah selesai mencapai tahap dua atau tahap pengembangan, sehingga lebih memungkinkan untuk mengetahui bagaimana implementasi program KRPL yang sudah berjalan di KRPL Kenanga.

Dalam pelaksanaan program KRPL ini juga berkembang yang namanya kampung tematik dengan tema Buang Sial (Buah Langka dan Tanaman Spesial) pada tahun 2016-2017, kelurahan RW 11 ini memiliki showroom kampung belantik. Dengan showroom tersebut, masyarakat atau kelompok yang berkunjung dari luar ke kelompok KRPL Kenanga ini bisa berbelanja beberapa macam buah dan tanaman dengan cara memetik sendiri dari kebun/showroom tersebut. Didalam setiap RT di kelurahan 11 memiliki icon sendiri-sendiri. Sedangkan untuk icon nya kampung belantik ini sendiri ada kebun cabai, buah tin, jambu madu, dan buah naga. Untuk produknya dari kita sendiri ada sambal, karena memang icon nya adalah cabai. Ada 6 industri sambal yang di produksi oleh anggota KRPL Kenanga ini dan masing-masing berbeda harganya.

Selain sambal juga ada jahe bubuk instan, teh daun tin, puding daun tin, nugget lele, dan stik dari sawi yang diproduksi. Untuk pemasarannya sendiri, produk-produk itu dijual di berbagai kesempatan, misalnya bazar, acara kunjungan dari beberapa instansi maupun hanya antar tetangga. Untuk hasil tanaman, KRPL Kenanga ini tidak memasarkan keluar, buahnya yang dijual keluar hanya seperti buah tin, jambu madu, dan buah naga. Proses pemasarannya pun hanya sekali panen, karena langsung habis. Terkadang menerima pesanan via online jika ketersediaan masih ada. Kalau untuk sayuran, KRPL Kenanga hanya bertukar atau barter. Ketika panen dibagi-bagi dan dimanfaatkan bersama, dimakan bersama. Begitupun dengan bibit, dibagi bersama. Untuk beberapa hasil tanaman yang berada dirumah-rumah, biasanya juga dititipkan di toko-toko untuk dijual atau dikirim ke PKK corner, dan juga ke warung-warung.

Terkait dengan bantuan dana yang diberikan pemerintah melalui Dinas Pertanian dan Ketahanan Pangan Kota Malang yang bersumber dari APBN, setiap tahunnya berbeda. Berdasarkan fakta yang terungkap melalui hasil penelitian, dapat disimpulkan program KRPL Kenanga sudah berjalan baik sesuai rencana yang disusun sebelumnya. Tetapi, untuk dapat tetap berjalan baik maka harus ada pendanaan berkesinambungan sehingga pelaksanaan program dapat berjalan lancar tanpa kendala dan kegiatan program KRPL dapat berjalan berkelanjutan.

\section{$>$ Evaluasi}

Tahap evaluasi dilaksanakan dengan tujuan mengetahui perkembangan pelaksanaan kegiatan dan melakukan penilaian kesesuaian kegiatan yang telah dilaksanakan. Hasil temuan penelitian pada data yang telah dipaparkan sebelumnya menunjukkan keberhasilan program KRPL di Kelurahan Merjosari 
dalam mencapai tujuannya ini dinilai melalui pelaksanaan monitoring dan evaluasi yang dilaksanakan secara berkala minimal sebanyak dua kali dalam setahun. Keberhasilan program juga ditandai dengan peningkatan pemahaman, kesadaran dan partisipasi anggota terhadap program KRPL di Kelurahan Merjosari.

Monitoring dan evaluasi program KRPL yang telah dilaksanakan oleh Dinas Pertanian dan Ketahanan Pangan Kota Malang dilakukan dengan menggunakan instrumen penelitian, meliputi tingkat partisipasi anggota kelompok, struktur organisasi, kelengkapan administrasi kelompok dan pertemuan kelompok. Seluruh komponen yang dinilai tersebut yang menentukan keberhasilan pelaksanaan program KRPL di Kota Malang pada umumnya, dan Kelurahan Merjosari pada khususnya. Selain dari dinas, monitoring dan evaluasi juga dilakukan oleh Kabid Ketahanan Pangan, Dirjen, dan Badan Ketahanan Pangan Pusat. Monitoring dan evaluasi ini dilakukan secara terjadwal maupun situasional sesuai dengan jadwal, karena terkadang monitoring yang dilakukan juga diadakan secara mendadak.

\section{b. Model Implementasi best practice kebijakan KRPL}

Dalam penelitian ini, peneliti menggunakan salah satu model implementasi top down tersebut, yaitu teori yang dikemukakan George C. Edward III (dalam Agustino, 2008:156), yaitu model Direct and Indirect Impact on Implementation. Adapun 4 variabel yang menjadi bagian dari analisis kebijakan publik berdasarkan teori tersebut adalah sumber daya pelaksana kebijakan, komunikasi, disposisi dan struktur birokrasi.

Berdasarkan hasil penelitian, dapat diketahui bahwa empat variabel tersebut menjadi kriteria penting dalam implementasi suatu kebijakan. Berikut akan dibahas uraian masing-masing kondisi variabel yang mempengaruhi impelemtasi kebijakan program KRPL di Kelurahan Merjosari:

$>$ Sumber daya pelaksana kebijakan

$\checkmark$ Staf, berdasarkan hasil penelitian, kondisi dan kecukupan sumber daya manusia sudah baik, jumlah dan kompetensi staf implementasi program KRPL juga sudah cukup memadai.

$\checkmark$ Informasi, ketetapan informasi yang diperoleh pelaksana di lapangan sudah baik. Informasi diberikan kepada pelaksana di lapangan sudah sesuai dengan pedoman umum, pedoman pelaksana dan petunjuk teknis yang ada. Namun informasi itu jarang di dapatkan kelompok karena jarang ada pelatihan.

$\checkmark$ Wewenang, berdasarkan hasil penelitian, diketahui bahwa pemahaman pelaksana terhadap wewenang yang dimiliki sudah baik. Pemahaman pelaksana terhadap wewenang sudah sesuai dengan tupoksi dan pembagian tugas yang ditetapkan.

$\checkmark$ Fasilitas, untuk fasilitas yang dimiliki berada dalam kondisi baik, jika terdapat kendala maka akan segera dilaporkan untuk di benahi.

Komunikasi

$\checkmark$ Transmisi, transmisi atau penyaluran komunikasi sudah berlangsung baik diantara implementator kebijakan karena sering diadakan pertemuan konsolidasi program dan rapat evaluasi program.

$\checkmark$ Kejelasan, kejelasan komunikasi sudah berlangsung baik diantara implementator kebijakan. Dinas Pertanian dan Ketahanan Pangan Kota 
Malang selaku penanggung jawab berkomunikasi secara jelas dan akurat agar tidak ambigu.

$\checkmark$ Konsistensi, konsistensi komunikasi sudah berlangsung baik diantara implementor kebijakan. Dinas Pertanian dan Ketahanan Pangan Kota Malang juga sudah memberikan instruksi yang jelas kepada pelaksana di lapangan.

\section{Disposisi}

$\checkmark$ Pengangkatan Birokrat, berdasarkan hasil penelitian, diketahui bahwa pengangkatan birokrat sudah dilaksanakan dengan baik. Dalam pengangkatan birokrat, diberikan pengumuman melalui media cetak dan pengumuman dengan kualifikasi yang sesuai dengan kebutuhan. Pengumuman juga dilakukan di kantor dinas, di seleksi dan di tetapkan oleh Kepala Dinas.

$\checkmark$ Insentif, untuk insentif sudah tersedia dengan memadai. Sudah ada ketentuan untuk tersedianya insentif para implementor kebijakan. insentif tersebut bersumber dari APBN.

Struktur Birokrasi

$\checkmark$ Standard Operating Prosedures (SOPs), berdasarkan hasil wawancara diketahui bahwa belum ada SOP yang jelas dalam pelaksanaan KRPL.

$\checkmark$ Fragmentasi, untuk fragmentasi atau penyebaran tanggung jawab sudah dilaksanakan dengan baik. Penyebaran tanggung jawab dilakukan sesuai dengan tupoksi dan penuh tanggungjawab karena sesuai dengan hasil rapat dan penunjukan dari kepala Dinas Pertanian dan Ketahanan Pangan Kota Malang.

3. Faktor pendukung dan penghambat yang dihadapi dalam melaksanakan pemberdayaan kelompok tani KRPL Kenanga melalui kebijakan program KRPL di Kelurahan Merjosari

\section{a. Faktor Pendukung}

$>$ Partisipasi Masyarakat

Wujud partisipasi kelompok tani KRPL Kenanga dalam upaya pemberdayaan ini diwujudkan dalam bentuk seperti keikutsertaan anggota untuk menghadiri rapat-rapat anggota, memberi ide atau gagasan, menyumbang kegiatan KRPL, baik berupa tenaga, uang ataupun barang yang sepadan dengan manfaat yang diterima, misalnya tanaman toga, sayur mayur, buah dan lain sebagainya. Bagi anggota yang tidak mempunyai kesempatan mengikuti kegiatan, maka mereka berpartisipasi dengan memberikan uang atau barang sebagai bentuk dukungan dan keikutsertaan mereka mengikuti kegiatan KRPL.

Berdasarkan fakta yang terungkap melalui hasil temuan peneliti, disimpulkan bahwa partisipasi anggota KRPL dalam melaksanakan program KRPL cukup tinggi. Bertambahnya anggota KRPL dari yang awalnya 15 menjadi 24 merupakan wujud dari tingginya partisipasi masyarakat mengikuti program KRPL tersebut.

\section{$>$ Kesadaran Masyarakat}

Keikutsertaan masyarakat dalam suatu program, dalam hal ini program KRPL bukan timbul begitu saja, tetapi karena adanya faktor yang mendorongnya berpartisipasi. Salah satu diantaranya adalah faktor kesadaraan masyarakat itu sendiri. Dengan kesadaran yang muncul, masyarakat mampu berperan aktif 
dalam mengikuti pelaksanaan program pemberdayaan yang telah dicanangkan oleh pemerintah, salah satunya yaitu program KRPL.

Sebagaimana pengertian kesejahteraan menurut Todaro dan Stephen C. Smith (2006:22). Dalam kaitannya dengan pengertian kesejahteraan tersebut, maka dapat dikatakan bahwa dalam upaya memberdayakan kelompok tani KRPL Kenanga melalui program KRPL dengan upaya meningkatkan kesejahteraan masyarakat dapat dikatakan berhasil dan mampu meningkatkan kesejahteraan masyarakat. Hal ini dibuktikan salah satunya dengan peningkatan kemampuan dan pemerataan distribusi kebutuhan dasar seperti makanan, karena masyarakat dapat memenuhi kebutuhan pangan sehari-hari hanya dengan memetik hasil dari tanaman yang mereka tanam. Kemudian peningkatan tingkat kehidupan dan tingkat pendapatan, yang mana anggota KRPL dapat memiliki pendapatan dengan menjual hasil tanaman yang mereka tanam tersebut.

\section{b. Faktor Penghambat}

$>$ Sedikitnya pemahaman anggota kelompok mengenai teknologi produksi atau teknik budidaya tanaman

Berdasarkan hasil wawancara dan observasi, anggota KRPL Kenanga membutuhkan informasi pertanian yang berkaitan dengan teknologi produksi atau teknik budidaya tanaman, hal ini disebabkan karena teknologi budidaya pertanian yang belum dikuasai oleh anggota KRPL. Informasi yang dibutuhkan oleh anggota KRPL Kenanga adalah informasi yang berkaitan dengan cara melakukan penanaman yang baik dan benar, cara melakukan perawatan pada tanaman, serta dasar-dasar melakukan budidaya dengan menggunakan teknologi hidroponik.

> Jarangnya dilakukan kegiatan pendampingan dan pelatihan kepada anggota KRPL Kenanga

Hambatan selanjutnya adalah kurangnya diadakan pelatihan, sosialisasi untuk mendapatkan informasi mengenai budidaya yang berhubungan dengan penanaman, perawatan dan budidaya tanaman. Informasi terkait penanaman yang dibutuhkan seperti manfaat dari masing-masing tanaman, cara melakukan penanaman yang baik dan benar, cara membuat pupuk sendiri dan lokasi pemberian sarana produksi yang tepat.

Sebagaimana hasil temuan peneliti, dapat disimpulkan bahwa pelatihan yang diadakan, baik dari Dinas Pertanian dan Ketahanan Pangan Kota Malang maupun dari PPL pendamping kelompok KRPL jarang dilaksanakan. Dengan begitu, maka informasi yang mereka dapatkan kurang. Beberapa dari anggota kelompok tani KRPL mengakui bahwa kebanyakan informasi yang mereka dapat dari sesama anggota KRPL dan internet. Kebanyakan mereka belajar menanam dengan sistem otodidak untuk melaksanakan kegiatan KRPL

Dari beberapa faktor penghambat yang dihadapi, maka untuk mengukur sejauhmana implementasi kebijakan program tersebut dapat dilihat menggunakan enam kriteria evaluasi kebijakan menurut William N. Dunn (2003:429) yaitu efektifitas, efisiensi, kecukupan, perataan, responsivitas dan ketepatan. 


\section{KESIMPULAN}

Berdasarkan hasil pembahasan penelitian yang telah dilakukan, dapat diambil beberapa kesimpulan dan saran terkait dengan hasil penelitian ini:

1. Peran aktor dalam melaksanakan pemberdayaan kelompok tani KRPL Kenanga melalui kebijakan program KRPL

> Peran Dinas Pertanian dan Ketahanan Pangan Kota Malang sebagai dinamisator.

$>$ Pemerintah Kelurahan berperan sebagai fasilitator.

$>$ Kelompok tani KRPL Kenanga telah berperan memberikan kontribusi terhadap keberlangsungan pangan dan peningkatan keberdayaan kelompok

2. Implementasi kebijakan program KRPL di Kelurahan Merjosari:

$>$ Proses implementasi implementasi kebijakan program KRPL Kenanga meliputi tiga tahapan, yaitu perencanaan, pelaksanaan dan evaluasi. Tahapan yang dilaksanakan kelompok penerima program tersebut sudah sesuai dengan petunjuk teknis Optimalisasi Pemanfaatan Lahan Pekarangan Melalui KRPL tahun 2018.

$>$ Sedangkan untuk model implementasi best practice kebijakan program KRPL di Kelurahan Merjosari ini, peneliti menggunakan model implementasi top down yaitu teori yang dikemukakan George C. Edward III (dalam Agustino, 2008:156), yaitu model Direct and Indirect Impact on Implementation. Adapun 4 variabel yang menjadi bagian dari analisis kebijakan publik berdasarkan teori tersebut adalah sumber daya pelaksana kebijakan, komunikasi, disposisi dan struktur birokrasi.

3. Faktor pendukung dan faktor penghambat dalam melaksanakan pemberdayaan kelompok tani KRPL Kenanga

$>$ Faktor pendukung yang dihadapi meliputi partisipasi anggota KRPL Kenanga dan kesadaran masyarakat dalam melaksanakan program KRPL yang cukup tinggi, dibuktikan dengan bertambahnya anggota KRPL dari yang awalnya 15 menjadi 24 .

$>$ Faktor penghambat yang dihadapi meliputi sedikitnya pemahaman anggota kelompok mengenai teknologi produksi atau teknik budidaya tanaman dan jarangnya dilakukan kegiatan pendampingan dan pelatihan kepada anggota KRPL Kenanga.

\section{SARAN}

1. Bagi pemerintah (Dinas Pertanian dan Ketahanan Pangan Kota Malang) hendaknya berupaya melakukan perbaikan untuk mengatasi kendala yang ada dengan cara memberikan pembinaan rutin, pelatihan dan sosialisasi secara intensif misalnya satu bulan sekali, serta melakukan evaluasi secara berkala antara pelaksana lapangan KRPL dan pihak kelompok penerima manfaat program.

2. Bagi pihak Kelurahan Merjosari, sebaiknya tidak hanya memberi dukungan berupa penyediaan fasilitas kegiatan yang diperlukan, tetapi juga membantu mencarikan informasi mengenai kemitraan, agar hasil dari kegiatan KRPL Kenanga bisa di pasarkan oleh mitra kerja yang sudah mendapat kepercayaan, sehingga hasil pemasaran KRPL Kenanga dapat berjalan secara stabil.

3. Bagi anggota kelompok tani KRPL Kenanga, diharapkan dapat memaksimalkan sumber informasi yang dimiliki, seperti menggunakan aplikasi Whatsapp yang ada untuk melakukan pertukaran informasi.

4. Bagi peneliti selanjutnya dengan topik yang relevan terhadap penelitian ini, diharapkan dapat melakukan pengembangan agar memperoleh hasil penelitian yang lebih baik lagi, sehingga dapat memberikan masukan yang membangun untuk pemerintah (Dinas Pertanian dan Ketahanan Pangan Kota Malang dan Penyuluh Pendamping Lapangan kelompok) 


\section{DAFTAR RUJUKAN}

\section{Buku:}

Agustino, Leo. 2017. Dasar-dasar Kebijakan Publik. Bandung: Alfabeta.

Dunn, William N. 2003. Pengantar Analisis Kebijakan Publik. Yogyakarta: Gajah Mada University Press.

Edward III, George, C. 1980. Implementing Public Policy. Washington DC: Congressional Quarterly, Inc.

Grindle, Merilee S. 1980. Politics and Policy Implementation in the Third World. Princeton University: Pricenton, NJ.

Hamidi, Jazim. 2004. Metode Penelitian Kualitatif. Malang: UMMP Press.

Lincoln, Y.S. \& Guba, E.G. 1985. Effective Evaluation. San Francisco: Jossey-Bass ublishers.

Moleong, Lexy J. 2000. Metodologi Penelitian Kualitatif. Bandung: PT. Remaja Rosda Karya.

Moleong, Lexy J. 2010. Metodologi Penelitian Kualitatif. Bandung: PT. Remaja Rosda Karya.

Spradley, J.P. 1980. The Participation Observation. New York: Reinhart \& Winston.

Sugiyono. 2006. Metode Penelitian Kuantitatif, Kualitatif dan R\&D. Bandung: Alfabeta.

Sugiyono. 2016. Metode Penelitian Kuantitatif, Kualitatif dan R\&D. Bandung: Alfabeta.

Sumodingningrat. 2004. Kemitraan dan Model-model Pemberdayaan. Yogyakarta: Gava Media.

Usman, Sunyoto. 2008. Pembangunan dan Pemberdayaan Masyarakat. Yogyakarta: Pustaka Pelajar.

Van Meter, Donald S. \& Van Horn, Carl E. 1975. The Policy Implementation Process; A Conceptual Framework. Beverly Hills: Sage publication.

Wahab, Abdul. 2008. Analisis Kebijakan dari Formulasi ke Implementasi Kebijakan Negara. Jakarta: Bumi Aksara.

\section{Sumber lainnya:}

\section{Jurnal:}

Arin Sugiarti dan M. Farid Ma'ruf, S.Sos, M.AP. 2015."Strategi Pemberdayaan Masyarakat Petani Melalui Program Pengembangan Usaha Agribisnis Perdesaan (PUAP) di Kabupaten Ponorogo." jurnalmahasiswa.unesa.ac.id.

Muhammad Nurdin. 2014. "Peran Pemerintah Daerah dalam Pemberdayaan Masyarakat Petani Jagung Kecamatan Biringbulu Kabupaten Gowa." journal.unismuh.ac.id

Shita Anggun Lowisada. 2014. "Pemberdayaan Kelompok Tani dalam Meningkatkan Pendapatan Usaha Tani Bawang Merah." jimfeb.ub.ac.id.

Sri Susanti. 2015. "Peranan Pemerintah Desa dalam Pemberdayaan Masyarakat di Desa Sukamaju Kecamatan Tenggarong Seberang”. ejournal.an.fisip-unmul.ac.id.

\section{Undang-Undang:}

Undang-undang No.6 Tahun 2014 tentang Desa yang merujuk pada Peraturan Pemerintah No.47 Tahun 2015.

Peraturan Pemerintah No. 17 Tahun 2015 tentang pangan.

Peraturan Menteri Pertanian Nomor 15/Permentan/OT.140/2/2013 Tentang Ketahanan Pangan

Keputusan Menteri Pertanian Republik Indonesia Nomor 62/Kpts/RC.110/J/12/2017 Tentang Petunjuk Teknis Optimalisasi Pemanfaatan Lahan Pekarangan Melalui Kawasan Rumah Pangan Lestari Tahun 2018

Website:

Anonymous. 2015. RW 11 Merjosari Lowokwaru Kota Malang. Diakses dari rw11vbt.com pada tanggal 19 Oktober 2017, pukul 08.32. 
Anonymous. 2016. Model Kawasan Rumah Pangan Lestari. Diakses dari http://jakarta.litbang.pertanian.go.id, pada tanggal 21 Oktober 2017, pukul 09.10.

Arif, 2012. Peran dan fungsi pemerintah, pada 12 februari 2012 diakses dari http://arifgii.blogspot.com/2012/12/peran-dan-fungsi-pemerintahan.html. pada tanggal 25 November 2017, pukul 08.09

Inggriani. 2015. Pemberdayaan Sumber Daya Manusia. Diakses dari https://dokumen.tips/documents, pada tanggal 21 Oktober 2017, pukul 09.27. 